\title{
HOW DOES THE STATE DESTROY INCENTIVES IN INNOVATION FINANCING?'
}

Edina Berlinger ${ }^{2}$

\begin{abstract}
We investigate the effect of state subsidy on the behavior of entrepreneur and venture capitalist in a double moral hazard and fixed investment model under positive externalities. We infer that investment subsidy and success fee improve the incentives, ease credit rationing, hence boost private financing, which explains the popularity of hybrid venture capital systems. The main disadvantage of these systems is, however, that the entrepreneur is encouraged to minimize his/her own capital investment and to ask for the maximal state subsidy available. It may happen that public sources go to entrepreneurs capable to finance their projects privately, so state subsidies increase state deficit (and private profits) without any effects on public welfare leaving other important areas underfinanced. We also prove that state guarantee definitely creates perverse incentives, hence it is not recommended in our model.
\end{abstract}

JEL-codes: $\mathrm{D}_{21}, \mathrm{G}_{3} 8, \mathrm{H}_{32}, \mathrm{H}_{5} \mathrm{O}, \mathrm{O}_{3} 8$

Keywords: innovation financing, venture capital, state subsidy, moral hazard

\section{INTRODUCTION}

We distinguish inventor and innovator in an innovation process, the former has a new idea, whereas the latter possesses already a patent, a product, a project, or even a formal enterprise (Stiglitz-Greenwald, 2014). The first question arising in economic policy is to decide to what extent invention or innovation should be subsidized by the state. Stiglitz-Greenwald (2014, Chapter 6, Appendix D) presents the mutual interaction of the two areas: innovators monopolize common

1 This research was supported by János Bolyai Research Scholarship of the Hungarian Academy of Sciences and also by the UNKP-18-4 New National Excellence Program of the Ministry of Human Capacities.

2 Edina Berlinger: Corvinus University of Budapest, Department of Finance, professor, department chair 
knowledge (e.g. by patents), but also improve it by financing industrial research projects. Stiglitz-Greenwald (2014) analyze this dynamic interaction through an example of a fishpond where fishes symbolize new ideas, and fishermen are the innovators who occasionally spend some part of their profit for fish resettlement (invention). They prove that an external subsidy to fishermen decreases fish population and creates a steady state where also fishermen's profit will be smaller. Translating it, a subsidy of innovation withers fundamental research exhausting the "fishpond" of our common knowledge, and so the intervention will result in an opposite effect in the long run: both the level of innovation and the economic growth will get lower. It is a commonplace in economics that goods with positive externalities (i.e. with spill-over social impact), like fundamental research, will suffer underproduction if we leave everything to the market. This implies that the state should rather support and finance fundamental research than encourage innovation directly. Stiglitz-Greenwald (2014) identify a radical review of property rights and more subsidy on export as key tools for stimulating innovation. Mazzucato (2012) extends the concept of "entrepreneurial state" and describes the role of the state in fostering innovation in an overall strategic framework. In the sequel, we put aside this dispute and restrict ourselves to investigate the role of direct state subsidy in innovation on project realization.

The main characteristics of early-stage innovative projects are a high-level risk and uncertainty, a sharp asymmetry in information (the entrepreneur knows the project and his own efforts better than outer players), and significant positive externalities. These characteristics together make innovation much more difficult to finance. On the one hand, negative consequences of informational asymmetry, moral hazard, and adverse selection occur increasingly, so both contractual incentives and screening and monitoring systems must be set with an extra care (Jáki et al., 2017). On the other hand, requirements of risk management are contrary to incentive aspects in general, e.g. excessive safety results in complacency and laziness (Pauly, 1968).

Trade-offs get even more complicated if the state, or EU, or some other external supporter interfere in favor of positive externalities since subsidies modify also risks and incentives. Combining this with the high degree of uncertainty around innovation, we must be prepared that venture capital market will be neither complete (we cannot have an insurance for every future event), nor perfect (there may be significant frictions due e.g. to costs of transactions or agents), nor efficient (there may occur large mispricings). Also, Kornai (2010) emphasizes that flexible and accessible financing is a key condition for widespread innovation, see also (Berlinger, 2017). This means that a careful mechanism design can create high value.

In practice, complex contracts, screening mechanisms, and monitoring systems are developed to handle (or to reduce at least) the above problems (Karsai, 2013). 
A frequently applied structure is stage financing, and it is common to give strong control rights to the external financer (Aman-Lovas, 2015; Lovas et al., 2015). The main difference, however, between (active) financing of a venture capitalist and (passive) financing of a bank is that a venture capitalist participates actively in realizing the project by advising, reorganizing, networking, etc., and so she personally contributes to the success (or failure) of the project. Thus, we expect from an optimal financing scheme to motivate not just the entrepreneur but also the venture capitalist to make efforts, i.e. it should manage moral hazard on both sides.

For the sake of simplicity, we disregard the problems arising from risk management, uncertainty, adverse selection, transaction cost, etc. (we assume that the parties are risk neutral, every decision parameter is known, both entrepreneurs and financers are homogeneous, there is no transaction cost), and focus on the effect of state subsidy on single and double moral hazard in financing. We investigate double moral hazard in a model where entrepreneur and financer are extremely interdependent: the project has a positive net present value only if both entrepreneur and financer do their best for the success.

It is widespread in theoretical literature that state subsidy ruins incentives but helps to create positive externalities (increases free sources available), and the ultimate net change in welfare depends on which effect is stronger (Lovas-Mile, 2015). There are mixed results in the literature concerning the empirical experiences (Becsky-Nagy-Fazekas, 2017; Karsai, 2015 and 2018; Jáki-Molnár, 2017b), however, professionnals tend to agree that in Hungary, negative effects are dominating (Kállay, 2014).

We prove the surprising result that in our model, the motivation of the entrepreneur entails the same for the venture capitalist automatically, hence there is no significant difference in handling single or double moral hazard. This convergence of interest goes wrong only in the case of a state guarantee. The form and size of state subsidy are important: investment subsidy and success fee may create value if done properly, but guarantee (or bailout) destroys incentives, therefore, its optimal size is zero even in the case of large positive externalities. Thus, we model the symptoms of soft budget constraint (Kornai et al., 2003), but we cannot explain why it pays off for the state to intervene in this form, thus its reasons should be outside the framework of the model.

In Section 2, we present the optimal private financing contract assuming single or double moral hazard. In Section 3, the state enters as a new player providing investment subsidy, success fee, or bailout (guarantee), and we analyze the characteristics of the optimum with three players. Finally, in Section 4 we deduce conclusions of the investigation. 


\section{PRIVATE FINANCING}

\subsection{Single moral hazard}

For our analysis, we elaborate on several extensions of the basic model of Tirole (2006, p. 115) about private financing under single moral hazard. We assume that the investment has a fixed volume which can be neither enlarged, nor narrowed down. This model fits better to describe specific innovative projects than the variable-size model assuming constant return-to-scale, see e.g. (Csóka et al., 2013; Berlinger et al., 2015 and 2017). This latter is characteristic rather for developed industries, e.g. if we want to model their international expansion. Thus, the entrepreneur has a project which requires an initial investment $I$. The entrepreneur has, however, a smaller initial capital (investment asset) $A$. She must acquire the missing capital $(I-A)$ from external sources or has to give up the project and forget about its benefits.

The project consists of a single period (from $t=0$ to $t=1$ ) and has two possible outcomes: either it succeeds with probability $p$, or fails with probability $1-p$. The total cash-flow of the project is $R>0$, in the case of success, and zero in the case of failure, see Figure 1.

\section{Figure 1}

Total cash-flow of the project

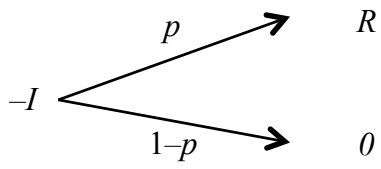

0.

Source: Tirole (2006, p.115.)

In the case of single moral hazard, the probability of the success of the project $(p)$ depends solely on the entrepreneur's behavior. If the entrepreneur makes all efforts for the success, i.e. if she behaves, then the success has a high probability $p=p_{H}$, whereas low efforts induce a low probability $p=p_{L}$ of success $\left(p_{H}>p_{L}\right)$ (Tirole, 2006, p.115.).

Misbehaving may occur in several forms, e.g. the entrepreneur is lazy (shirking); chooses a pet project, or one which makes her indispensable (entrenchment), or one providing more perks, or offering good circumstances to "help" friends and 
relatives. This latter takes us to illegal activities such as corruption, fraud, and stealing.

Misbehaving may attract entrepreneurs by generating a private benefit $B>0$ which can also be considered as personal expenses of good behavior.

Moral hazard arises in the model because the financer cannot monitor the behavior of the entrepreneur. This is a special case of informational asymmetry where the relation between financer and entrepreneur can be described as a special principal-agent relationship. If the entrepreneur, i.e. the agent is not motivated properly, then she will focus on her own interest instead of the principal's. Thus, moral hazard stems from rational profit maximization and not from low morality (Pauly, 1968). We assume that the project's private benefit (without externalities), i.e. its NPV (net present value) is positive only if behaving is guaranteed:

$$
\begin{aligned}
& N P V_{\text {behave }}>0>N P V_{\text {misbehave }} \\
& p_{H} R-I>0>p_{L} R-I+B
\end{aligned}
$$

Note that the project can be successful even in the case of the entrepreneur's misbehaving but with a smaller probability. The success of the project depends not just on the entrepreneur but also on circumstances and on good or bad luck.

For the sake of simplicity, we assume similarly to the basic model (Tirole 2006, p. 115.) that the external financer expects zero rate of return (there is no time preference, parties are risk neutral, and financers are perfectly competitive), and the entrepreneur has a limited liability, so cannot be forced for further payments after investing her initial capital $A$. It is the entrepreneur owning a special promising project, while there are many financers who are perfect substitutes for each other constituting thus a perfectly competitive market. The value is created on the entrepreneur's side. The entrepreneur offers the contract and the financers compete. We can interpret private financing as a contract design problem where two questions must be answered:

1. Will the project be financed?

2. How should the entrepreneur and the financer share the profit?

In the case of failure, the parties pay nothing to each other, so the second question asks how to distribute the income $R$ between entrepreneur $\left(R_{e}\right)$ and financer $\left(R_{i}\right)$ in the case of success. The contract must motivate the entrepreneur to behave. The inequality below expresses the condition that the entrepreneur's expected income should not be less under behaving than under misbehaving (incentive constraint): 
$p_{H} R_{e} \geq p_{L} R_{e}+B$

After rearranging and applying $\Delta p=p_{H}-p_{L}$, we obtain

$R_{e} \geq \frac{B}{\Delta p}$

This implies that $R_{e}$ must be at least $\frac{B}{\Delta p}$, otherwise, the entrepreneur would be undermotivated. Hence, the entrepreneur cannot promise (in present value) more than $p_{H}\left(R-\frac{B}{\Delta p}\right)$ called pledgeable income by (Tirole, 2006) and denoted by $\rho$.

On the other hand, we have to ensure that participation is worth also for the financer. The financer is risk neutral and his expected rate of return is zero, it is sufficient if his expected income is not less than his investment was (participation constraint):

$p_{H} R_{i} \geq I-A$

i.e.

$$
R_{i} \geq \frac{I-A}{p_{H}}
$$

Constraints (2) and (3) imply (relying on $R=R_{e}+R_{i}$ ) that the project can be financed only if the entrepreneur has an initial capital at least $\bar{A}$ (necessary condition for financing):

$A \geq \bar{A}=p_{H} \frac{B}{\Delta p}-\left(p_{H} R-I\right)=I-p_{H}\left(R-\frac{B}{\Delta p}\right)=I-\rho$

We can interpret (4) so that the NPV $\left(p_{H} R-I\right)$ of the project and the entrepreneur's initial capital $(A)$ together should cover the agency cost $p_{H} \frac{B}{\Delta p}$. We can also say that the initial capital and the pledgeable income should be sufficient for the investment.

Observe that (4) is also a sufficient condition of financing since we assumed that the competition of financers is perfect, so (3) holds with equality. The parameters and decision rules are known by both parties and the entrepreneur offers the contract, so the entrepreneur will declare only the minimal necessary capital $A=\bar{A}$. Thus, the entrepreneur's initial capital in optimum is

$A^{o p t}=I-\rho$ 
Hence, our answer to the above Question 1 of type "to be, or not to be" is that due to moral hazard, it can occur that even projects with very high NPV are not financed if the entrepreneur's capital is not sufficient. This is moreover true if the entrepreneur's potential private profit $(B)$ is big under misbehaving and/or if good behavior improves just slightly the probability of success ( $\Delta p$ is small).

Answering Question 2 about the sharing rule, the total profit (NPV) of the project remains at the entrepreneur, but she can get it only in the case of success, and this motivates her to make efforts. The expected value of the financer's share equals just her investment:

$$
\begin{gathered}
R_{e}=R-R_{i} \\
R_{i}=\frac{I-A}{p_{H}}
\end{gathered}
$$

\subsection{Double moral hazard}

The model of single moral hazard in the previous subsection can be generalized in several ways for the case of double moral hazard when the financer is not a bank but a venture capitalist who (hopefully) actively contributes to the success of the project. In this paper, we assume that the efforts of the entrepreneur and financer are perfect complements of each other. Sometimes, entrepreneur and financer can partly substitute each other, see e.g. (Tirole, 2006, p. 364.), but the model presented in this paper reflects the interdependence of the two parties better.

Assuming perfect complements, the higher probability of success $p_{H}$ can be achieved via efforts of both parties, and if any of them misbehaves, then the probability decreases to $p_{L}$, so the efforts of one player cannot make up the efforts of the other one.

We keep assuming that the behavior of the players matters, i.e. there exists moral hazard. We have to modify (1) in order that even a joint misbehaving of both parties should not be worth for them:

$p_{H} R-I>0>p_{L} R-I+B+C$

where $C$ denotes the venture capitalist's private profit (in other words, the cost of her efforts, $C>0$ ).

Note that (7) is stricter than (1), so we optimize on a smaller set and if something satisfies (7), then it automatically meets also (1). 
We require now, too, the entrepreneur's incentive constraint (2) and the financer's participation constraint (3). As a new condition, we have the venture capitalist's incentive constraint which can be obtained similarly to the entrepreneur's incentive constraint:

$$
R_{i} \geq \frac{C}{\Delta p}
$$

We claim that the optimal initial capital (5) deduced from (2) and (3) arising under single moral hazard is still optimal in this new situation. We just have to show that (5) satisfies also (8). This can be verified by a simple calculation relying on

$\Delta p R>B+C$

which is a consequence of (7).

Thus, it is a surprising result that in the model of double moral hazard assuming a perfect complementary relation between entrepreneur and financer, the optimal financing contract is the same as the one under single moral hazard. In other words, replacing a passive bank by an active venture capitalist does not influence the size of the entrepreneur's initial capital to start the project, the entrepreneur must possess an initial capital $\bar{A}$ now, too, to get finance.

We note that the exact information about the other player's private profit ( $B$ and $C$ ) is essential (common knowledge). However, in the case of informational asymmetry, i.e. if each player knows only her own private profit, then this involves not just moral hazard but also adverse selection which can be managed by sophisticated screening and signaling mechanisms (Lovas, 2015). In this aspect, the initial capital offered by the entrepreneur and the one required by the financer may grow to a very important factor.

\section{STATE SUBSIDY}

In this section, we investigate what happens if the entrepreneur can finance her project not only from venture capital but also (fully or partially) from state subsidy. The operation of hybrid venture capital funds (i.e. funds combining private and public resources) is described in (Lovas-Mile, 2015; Lovas-Riz, 2016; JákiMolnár, 2017a; Karsai, 2018).

We introduce positive spillover effects (externalities) $(E>0)$ into the double moral hazard model described in the previous section. These externalities appear in- 
dependently from the success or failure of the project for example in the form of knowledge transfer, increased employment, or economic activity similarly to (Berlinger et al., 2015 and 2017). We suppose that externalities turn up in the state budget as explicit incomings at $t=1$. Of course, private players do not take these positive effects into consideration, these are important only for the state. We will see that state has interest in the realization of the project even if venture capital market is not functioning well, or if private financing is not available due to insufficient initial assets of the entrepreneur.

The present value of state subsidy $\tilde{S}$ cannot exceed the extra budget income coming from externalities $E$ (budget constraint):

$\tilde{S} \leq E$

State subsidy is a non-refundable lump sum payment and can have three forms: it can be received at the beginning of the project (investment subsidy); or at the end of the project in the case of success (success fee); or in the case of failure (bailout or guarantee). We are still referring to Figure 1 where there are three states of the world: the present and the two possible future states. State subsidy forms under investigation relate to the so-called Arrow-Debreu securities, and more complex subsidy forms can be built up from these basic elements.

In the next subsections, we present models with three players: entrepreneur, venture capitalist, and state. Moral hazard can be double-sided on the part of the entrepreneur and/or the venture capitalist as in 2.2. We suppose (7), i.e. the behavior of the entrepreneur and venture capitalist matters from the point of view of NPV. There is no moral hazard related to the state because the state gives a passive support without participating in the realization of the project, hence her effort is not needed for the success. Of course, in reality, there may be inefficiencies and malfeasances during the determination of subsidy structures and the selection of the winning projects, but these are set aside, and we assume that state intervenes in an optimal way maximizing the aggregate utility of the project. The aggregate utility of the project $(U)$ (in present value) is defined as the sum of the net present value $(N V P)$ and the externalities $(E)$ of the project minus the present value of state subsidy $(\tilde{S})$ :

$U=N P V+(E-\tilde{S})=$ profit of enterpreneur + budget surplus

This is a strong assumption because private benefits $(N P V)$ and public benefits $(E-\widetilde{S})$ are equally important to the state. Moreover, we exclude all public failures 
that can be relevant in practice, for example, in reality, state is composed of individuals following their self-interest and conflicting with each other, state does not have all the necessary information, and state can take not only economical but also political aspects into consideration when shaping its economic policy. In the following models, the state is infinitely well-intentioned, self-consistent, omniscient, omnipotent, and maximizes welfare in the narrow sense of (11) under the budget constraint of (10). Due to these simplifying assumptions, we can focus on the behavior of the entrepreneur and venture capitalist and the related moral hazard issues.

In the following, we introduce different state subsidy forms (investment subsidy, success fee, guarantee) one by one, thus we examine three different cases. We suppose that it is the entrepreneur who gets the state subsidy.

When determining the optimal size of the state intervention, we have to consider some thresholds:

- 0 is a lower bound excluding those situations when the state gives a negative subsidy, for example, taxes innovative projects.

- $S^{\max }$ is an upper bound coming from the state's budget constraint.

- $\bar{S}$ is a threshold (can be both upper bound and lower bound) where the entrepreneur is just able to get private financing from the venture capitalist which is also the threshold of good behavior of the entrepreneur.

In general, the optimal size of state subsidy depends on the relative position of these thresholds:

$$
S^{o p t}=f\left(0, S^{\max }, \bar{S}\right)
$$

We define $S^{\text {opt }}$ in a special case by listing all relevant thresholds in a table, then describing their meaning and their possible relative positions, and finally maximizing (11).

\subsection{Investment subsidy}

In the case of an investment subsidy, the incentive constraint of the entrepreneur (2) remains unchanged. However, the participation constraint of the financer (3) is modified, as due to state subsidy, the entrepreneur needs less outside financing to launch her project.

$p_{H} R_{i} \geq I-A-S$ 
The incentive constraint of the financer (8) does not change. As financers are perfectly competitive, (13) holds with equality. Expressing $R_{i}$ from this and substituting it into (2), we get a necessary condition of private financing in the case of investment subsidy:

$A \geq \bar{A}_{\text {investment subsidy }}=p_{H} \frac{B}{\Delta p}-\left(p_{H} R-I\right)-S=I-\rho-S$

As previously, we can suppose that (13) and (14) hold with equality. Expressing $A$ from (14), computing $R_{i}$ from (13), and substituting it into (8), we get by (7) that the incentive constraint of the financer holds automatically. Therefore, (14) is not only a necessary but also a sufficient condition of private financing. Intuitively, the entrepreneur can use state subsidy as her own capital to finance the investment, thus she needs less initial capital on her own.

Table 1

State subsidy thresholds in the case of investment subsidy

\begin{tabular}{|c|c|c|c|}
\hline Sign & $\begin{array}{l}\text { Where } \\
\text { to calculate } \\
\text { from? }\end{array}$ & Value & Explanation \\
\hline $\bar{S}$ & (14) & $(I-A)-\rho$ & $\begin{array}{l}\text { - Below this level, the project can- } \\
\text { not be financed from private } \\
\text { funds, because the good behavior } \\
\text { of the entrepreneur is not ensured; } \\
\text { - Above this level, the state has no } \\
\text { interest to give subsidy, because } u \\
\text { would decrease }\end{array}$ \\
\hline$S^{\max }$ & $(10)$ & $E$ & $\begin{array}{l}\text { The state cannot give more due to its } \\
\text { budget constraint }\end{array}$ \\
\hline
\end{tabular}

Source: the author

It follows from $\rho>0$ that $\bar{S}<I-A$, i.e. state subsidy is smaller than the total outside financing need of the project, therefore, private financing is needed, as well. If the state is to maximize social utility $U$, it should give exactly $\bar{S}$ if affordable under the budget constraint.

The possible relative positions and the optimal size of state subsidy (black dots) are presented in Figure 2. 


\section{Figure 2}

\section{Relative positions of thresholds in the case of investment subsidy}

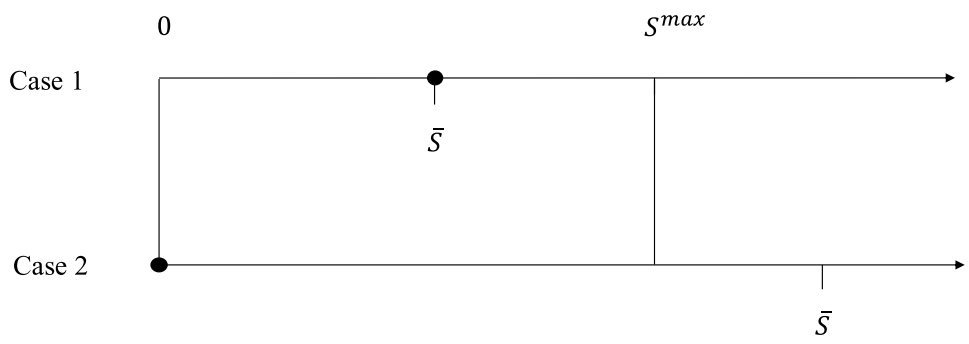

Source: the author

In Case 1 of Figure 2, the optimal size of state subsidy is $\bar{S}$ and a surplus of $E-\bar{S}$ will remain in the state budget. State subsidy creates value both at private and public levels as it completes the resources of the entrepreneur and makes the project real which could not have been financed by venture capitalists due to moral hazard.

In Case 2 of Figure 2, the project has too small positive externalities, thus the maximum affordable state subsidy does not help to reach the level needed for private financing. In this case, the project is not worth to be subsidized, because private funds are not available due to moral hazard, so the project cannot be realized.

The optimal size of state subsidy is, therefore:

$$
S^{o p t}=\left\{\begin{array}{ll}
\bar{S} & \text { if } \bar{S} \leq S^{\max } \rightarrow \text { project is realized } \\
0 & \text { if } \bar{S}>S^{\max } \rightarrow \text { project is not realized }
\end{array}\right\}
$$

Until now, we supposed that the entrepreneur reveals honestly how much initial capital she has. However, if the entrepreneur is rational and knows the reaction function (15) of the state, her optimal strategy is to declare an $A$ which is just necessary to draw down the maximal state subsidy and to get private financing. At this point, $\bar{S}=S^{\max }$, therefore:

$A^{o p t}=I-\rho-E$,

which will be lower than it would have been without state subsidy as $E>0$ (cf. (5)). We can conclude that in the optimum (when all the three players are optimizing), state subsidy will be larger than necessary for the realization of the project and there will remain no surplus in the state budget $\left(E-\bar{S}=E-S^{\max }=0\right)$. In this way, the entrepreneur gets not only the entire NPV of the project but also its externalities $E$. In other words, the entrepreneur can internalize all the externalities with the help of state subsidy. 


\subsection{Success fee}

In the case of a success fee, the incentive constraint of the entrepreneur (2) is changed:

$p_{H}\left(R_{e}+S\right) \geq p_{L}\left(R_{e}+S\right)+B$

The participation constraint of the financer (3) holds again with equality. Using (3) and (17), a necessary condition of private financing is:

$A \geq \bar{A}_{\text {success } f e e}=p_{H} \frac{B}{\Delta p}-\left(p_{H} R-I\right)-p_{H} S=I-\rho-p_{H} S$

Similarly to the case of an investment subsidy, we can prove that with $A=\bar{A}_{\text {successfee }}$, the venture capitalist's incentive constraint (8) also holds. Therefore, (18) is both a necessary and sufficient condition of private financing.

We see from (18) that the initial capital $\bar{A}$ of the entrepreneur needed for private financing is decreased by the expected value of the success fee, hence now the private investor is willing to take larger stake from the investment than without a success fee. Consequently, in this structure, state subsidy is not crowding out, but on the contrary, it is boosting private funding by improving the incentives of the entrepreneur.

Table 2

State subsidy thresholds in the case of a success fee

\begin{tabular}{|c|c|c|c|}
\hline Sign & $\begin{array}{c}\text { Where } \\
\text { to calculate } \\
\text { from? }\end{array}$ & Value & Explanation \\
\hline $\bar{S}$ & (18) & $\frac{(I-A)-\rho}{p_{H}}$ & $\begin{array}{l}\text { - Below this level, the project cannot be } \\
\text { financed from private funds, because } \\
\text { the good behavior of the entrepre- } \\
\text { neur is not ensured; } \\
\text { - Above this level, the state has no } \\
\text { interest to give subsidy, because } U \\
\text { would decrease }\end{array}$ \\
\hline$S^{\max }$ & (10) & $\frac{E}{p_{H}}$ & $\begin{array}{l}\text { The state cannot give more due to its } \\
\text { budget constraint }\end{array}$ \\
\hline
\end{tabular}

Source: the author 
The relative positions of the thresholds can be similar to those in Figure 2, so the optimal size of state subsidy is (15) as previously.

This raises the question again about the optimal size of the initial capital $A$ declared by the entrepreneur. It follows from the formula of $\bar{S}$ in Table 2 that a smaller initial capital $A$ leads to larger state subsidy $\bar{S}$. The entrepreneur has interest in reducing $A$ until $\bar{S}$ takes its maximum, i.e. $\bar{S}=S^{\max }$. Using formulas in Table 4, we get $A^{\text {opt }}=I-p-E$ exactly like in the case of investment subsidy. Now again, the entrepreneur gets all the NPV and the externalities of the project.

\subsection{Bailout}

In the case of a bailout (or guarantee), the state promises implicitly or explicitly that the entrepreneur will be saved in a failure. This alters the incentive constraint of the entrepreneur:

$p_{H} R_{e}+\left(1-p_{H}\right) S \geq p_{L} R_{e}+B+\left(1-p_{L}\right) S$

The incentive constraint (3) of the private financer remains the same. Using (20) and (3), the necessary condition of private financing is modified, and the initial capital $\bar{A}$ needed to start the project is increased relative to the base case:

$A \geq \bar{A}_{\text {bailout }}=p_{H} \frac{B}{\Delta p}-\left(p_{H} R-I\right)+p_{H} S$

In this case, an initial capital equal to $\bar{A}_{\text {bailout }}$ is not necessarily enough to ensure the motivation of the venture capitalist, this depends on the parameters, especially on $C$.

So, we can conclude that a state guarantee has an opposite effect than success fee: it destroys incentives, thus compromises private financing and increases the initial capital needed. In the spirit of (11), a state-financed bailout creates no value, moreover, it destroys value as fewer projects can be realized due to the increased initial capital requirement, thus NPV and $E$ get lost, whereas state expenses are increasing. In this model, therefore, the optimal size of a bailout is just zero.

A bailout is not worth to introduce even if the entrepreneur has an initial capital $I \leq A$ large enough to finance her project on her own. In this case, there is no need for private financing, but state subsidy may create perverse incentives for the entrepreneur to misbehave, hence the probability of success may drop down to $p_{H}$ which makes NPV negative according to (7). The project will be realized even in this case as the entrepreneur has enough money and has the interest to finance 
it. Therefore, state guarantee either does not change or decreases the NPV of the project, it does not change the externality $E$, while it definitely increases state expenses, which is not a good deal for the state by (11). Therefore, a state guarantee decreases the project's benefits $U$ even if venture capital is not needed.

Summing up, in these models, even large positive externalities do not justify state-financed bailout as it is just a present to the entrepreneur financed from public money which has no effect in the best case and effectively destroys incentives in the worst case.

\section{CONCLUSIONS}

We can answer now the question in the title of the paper: There are many ways how the state can destroy innovation financing.

The first problem is if the state spends too much on innovation financing and consequently neglects areas with weaker market mechanisms but of fundamental importance regarding not just innovation but the welfare of the entire community. Such areas are e.g. education and fundamental research.

Besides allocational difficulties, several problems can occur also in designing and operating subsidy systems if the state is unable or unwilling to maximize social welfare. There is a long list of state failures due to informational problems, bureaucratic coordination, or corruption, but even the definition of social welfare might be problematic. In the models of this paper, we assumed that all the three parties, namely entrepreneur, venture capitalist, and state possess all necessary information, make decisions along clear goals, and know also the reaction functions of each other. If this is not the case, and it definitely does not hold in the real world, then we get a lower efficiency.

A further difficulty can be if state subsidy harms the entrepreneur's incentives, we focus mainly on this problem in this paper. In our models, this cannot occur with an investment subsidy and success fee. If also private funding is needed to start a project, then misbehavior is excluded since private financer enters only with this condition, so the mere fact of private financing has a disciplining effect. If the entrepreneur finances the project alone with the help of state subsidy, then success ensures her to get the total profit without sharing it with others. As we assumed that the project's NPV is positive in the case of success and negative otherwise, it follows that the entrepreneur is motivated perfectly to make efforts in these circumstances, too. Hence, seemingly, an investment subsidy and success fee do not harm incentives, in fact, these get even improved in the frame of the model. This could be a nice example of cooperation between market and state where the latter compensates the missing capital bringing the project to a stage where private 
financing can already enter. State capital thus acts as a sort of catalyzer helping to realize projects which could not have been financed by the market without state subsidy.

This sounds nice, but the situation is not that advantageous, unfortunately. The possibility of investment subsidy or success fee motivates entrepreneurs to declare less initial capital, just as much as needed to get maximal possible state subsidy. Then the state spends all the externalities on the project in optimum, and the entrepreneur gets this extra gift from the public money besides the NPV. There will be many projects which could have been financed by the market, and the positive externalities would have remained in the state budget for community purposes, but the possibility of state subsidy makes entrepreneurs hide their own capital, and thus acquire all or most externalities for themselves. The state can practically never know the number of projects which would have been aborted without the subsidy program versus the ones which would have been realized anyway, and the entrepreneur used state subsidy just to acquire an extra profit. If the rate of the latter projects is large, then even an optimal state subsidy structure is wasting public money.

A starting point of the models was assuming that state subsidy does not modify the private profits ( $B$ and $C$ ) arising from the players' misbehavior. This is a realistic assumption in the case of shirking since the value of free time is always the same. Concerning other forms of abuse, however, state subsidy may even increase the private profits since state control may be weaker than the financer's control. Moreover, this may occur not just on the entrepreneur's side $(B)$, but also on the financer's side $(C)$ depending on the construction. If this effect is significant, then also investment subsidy and success fee can destroy incentives and the total effect will be negative.

By conditions of the model, guarantee (or bailout) acts as a perverse incentive, therefore, it is not recommended even with extremely large positive externalities. The optimal size of a state guarantee is zero in the model. In the real world, sometimes it may be conceivable that state guarantee still creates value, e.g. assuming risk-averse players when it is impossible or very hard to hedge risks on the capital markets, but we must be aware that this structure harms incentives seriously in any case and so the trade-off not necessarily pays off.

The model of guarantee demonstrates the phenomenon of soft budget constraint (Kornai et al., 2003) when the promise of state bailout perverts the behavior of the players and both the entrepreneur and the venture capitalist are less willing to work for the success of the project. Our theoretical model, however, gives no hints about the state's possible interest in a bailout, this must have reasons outside the model. Kornai et al. (2003) explain this phenomenon with time-inconsistent decision-making. 
Finally, we mention that the continuous investment model by Berlinger et al. (2015 and 2017) found that state subsidy creates value anyway even in the form of guarantee in the case of single moral hazard. Their paper concluded that the problems occurring in practice are due to errors in realization and not to state subsidy. In their model, the private financer could convert the wrong subsidy form, i.e. guarantee into success fee. Thus, we can expect financial intermediaries to transform not only cash-flow and risks but also incentives. In the present paper, however, we assumed that the state subsidizes the entrepreneur directly and the financer cannot change the subsidy system afterward. This difference implies the explicitly negative effect of guarantee now. Therefore, designing subsidy systems, we have to pay a distinguished attention to the cooperation with financial intermediaries, including the timing of state subsidy and private financing.

\section{REFERENCES}

Aman Sejla - Lovas Anita (2015): Overcoming Asymmetric Information in Venture Capital Finance: Theoretical Approach and Evaluation of Hungarian Findings [Információs aszimmetria kezelése a kockázati tőkés finanszírozásban: Elméleti megközelítés és a hazai tapasztalatok értékelése]. Külgazdaság 59(5-6), 80-99.

Becsky Nagy Patrícia - Fazekas Balázs (2017): Is the state on the ball? The effect of the states role on the demand side of venture capital [Résen van-e az állam? Az állami szerepvállalás hatása a kockázati tőke keresleti oldalára]. Közgazdasági Szemle 64(5), 507-527., https://doi.org/10.18414/ ksz.2017.5.507.

BERLINGER EdINA (2017): The role of the market and the state in innovation - Kornai János versus Joseph E. Stiglitz [A piac és az állam szerepe az innovációban - Kornai János versus Joseph E. Stiglitz]. Közgazdasági Szemle 64(4), 377-393., https://doi.org/10.18414/ksz.2017.4.377.

Berlinger Edina - Lovas Anita - Juhász Péter (2017): State subsidy and moral hazard in corporate financing. Central European Journal of Operations Research 25(4), 743-770., https://doi. org/10.1007/s10100-016-0461-8.

Berlinger Edina - Juhász Péter - Lovas Anita (2015): The effects of state subsidy on project financing under moral hazard and positive externalities. A contract theory approach. [Az állami támogatás hatása a projektfinanszírozásra erkölcsi kockázat és pozitív externáliák mellett: Szerződéselméleti megközelítés.] Közgazdasági Szemle, 62(2), 139-171.

Csóka, P. - Havran, D. - Szücs, N. (2013): Corporate financing under moral hazard and the default risk of buyers. Central European Journal of Operations Research 22(8),. 1-16.

JÁKi ERIKA - MolnÁR ENdre Mihály (2017a): Állami és uniós szerepvállalás a magvető életszakaszban lévő vállalkozások kockázatitőke-finanszírozásában. In: FARKAs BeÁtA - Pelle AnitA (szerk.): Várakozások és gazdasági interakciók. SZTE Gazdaságtudományi Kar Közleményei (Kari konferencia, Szeged, 2016.11.24-25), Szeged: JATEPress Kiadó, 2017, 97-110. (ISBN: 978963-315-348-2).

JÁki Erika - Molnár Endre Mihály (2017b): Model of the state and EU involvment in the venture capital market. In: Zoltayné Paprika Zita - Horák Péter - VÁradi Kata - Zwierczy k PéTer TAmás - Vidovics DAncs Ágnes - RÁdics Péter JÁnos (szerk.): ECMS 2017: 31st European Conference on Modelling and Simulation. Budapest, 2017.05.23-2017.05.26. Nottingham: ECMS- 
European Council for Modelling and Simulation, 2017, p. 120-126. (ISBN:978-0-9932440-4-9), https://doi.org/10.7148/2017-0120.

Jáki Erika - Molnár Endre Mihály - Walter György (2017): Government Sponsored Venture Capital: Blessing or Curse? Management (Slovenia) 12(4), 317-331., https://doi.org/10.26493/18544231.12 .

KÁLLAY LÁsZLó (2014): State subsidies and economic performance [Állami támogatások és gazdasági teljesítmény]. Közgazdasági Szemle 61(3), 279-298.

KARSAI, J. (2013): Venture Capital and Private Equity Industry in Hungary. Acta Oeconomica 63(1), 23-42.

KARSAI, J. (2015): Squaring the Circle? Government as Venture Capital Investor. Studies in International Economics: Special Issue of Külgazdaság 1(1), 62-93.

KarSAI, J. (2018): Government Venture Capital in Central and Eastern Europe. Venture Capital 20(1), 73-102.

Kornai, J. - Maskin, E. - Roland, G. (2003): Understanding the soft budget constraint. Journal of Economic Literature 41(4), 1095-1136. https://doi.org/10.1257/002205103771799999.

KornaI, J. (2010): Innovation and Dynamism. Interaction between Systems and Technical Progress. Economics of Transition, 18(4), . 629-670.

Lovas Anita (2015): The Risk of Adverse Selection and its Management in the Process of Venture Capital Investment. Economy and Finance: English-Language Edition of Gazdaság és Pénzügy 2(2), 186-200.

Lovas Anita - Mile Boglárka (2015): The effect of state intervention on venture capital investments under double moral hazard [Az állami beavatkozás hatása a kockázati tőke-befektetésekre kettős erkölcsi kockázat mellett]. Köz-Gazdaság 10(2), 87-101.

Lovas Anita - Pereczes János - Rába Viktória (2015) Incentives and Restrictions in Venture Capital Contracts. Financial and Economic Review, 14(3), 106-121.

Lovas Anita - Riz NiкоLetT (2016): Accelerator or Incubator? Enterprise Support Organisations in Hungary in Light of International Practice. Economy and Finance: English-Language Edition of Gazdaság és Pénzügy 3(4), 305-322.

Mazzucato, M. (2012): Innovation, the State, and Patient Capital. In: Jacobs, M. - Mazzucato, M. (eds.) (2012): Rethinking Capitalism: Economics and Policy for Sustainable and Inclusive Growth. Chichester, UK: Wiley-Blackwell. ISBN 9781119120957.

Pauly, M. (1968): The Economics of Moral Hazard: Comment. The American Economic Review 58(3), 531-537, https://doi.org/10.1017/cbo9780511528248.009.

Stiglitz, J. E. - Greenwald, B. C. (2014): Creating a Learning Society. A New Approach to Growth, Development, and Social Progress. New York, NY: Columbia University Press.

Tirole, J. (2006): Theory of Corporate Finance. Princeton, NJ: Princeton University Press. 